Юрий Андреевич ЛАБЫНЦЕВ 


\section{ПЕРВОПЕЧАТНИК ИВАН ФЕДОРОВ, РАБОТАВШИЙ В РУССКИХ, БЕЛОРУССКИХ И УКРАИНСКИХ ЗЕМЛЯХ ${ }^{1}$}

\section{Аннотация:}

В статье рассматривается деятельность знаменитого русского, белорусского и украинского первопечатника Ивана Федорова (ок. 1520 - 5 декабря 1583 года). В 1564 г. он выпустил в Москве первую точно датированную русскую книгу «Апостол», а затем несколько других книг. В конце 1560-х годов в имении белорусских православных магнатов Ходкевичей Заблудове Иван Федоров напечатал еще ряд изданий, в их числе «Евангелие учительное» 1569 г. А в 1570-х - начале $1580-\mathrm{x}$ годов во Львове и Остроге он издал ряд других книг. Среди них была и первая печатная Библия на церковнославянском языке - Острожская библия.

\section{Ключевые слова:}

Иван Федоров, кирилло-мефодиевское наследие, восточнославянская старопечатная книжность.

Abstract: Y.A. LABYNTSEV "THE FIRST PRINTER IVAN FYODOROV, WHO WORKED IN THE RUSSIAN, BELARUSSIAN AND UKRAINIAN LANDS".

The article discusses the activities of the famous first printer of Russia, Belarusia and Ukrainia Ivan Fyodorov (c. 1520 - 5th December 1583). In 1564 he issued in Moscow the first exactly dated Russian book «Apostle», and then a few other books. At the end of the 1560s on the manor of the Belarusian Orthodox magnates of Hotkevich's Zabludov, Ivan Fyodorov published a number of books, including «Didactic Gospel» in 1569. And from the 1570s to early 1580s in Lvov and Ostrog, he issued a number of other books. Among these publications were the first printed Bible in Church Slavonic: the Ostrog Bible.

\section{Keywords:}

Ivan Fyodorov, Cyril and Methodius heritage, East Slavic early printed book culture, Ostrog Bible.

И ван Федоров - русский, белорусский и украинский первопечатник, издатель первой датированной русской печатной книги. Точное время и место его рождения неизвестны, но в своих изданиях он постоянно подчеркивал собственное московское происхождение: «Ионн Федорович, друкарь Москвитин», «Иоанн Феодорович, печатник, з Москвы».

Книгопечатание в Москве появилось в середине XVI в., когда по повелению царя Ивана Грозного и благословению митрополита Макария в 1563 г. была основана столичная типография, начало и успешное развитие которой связано с деятельностью Ивана Федорова и Петра Тимофеева Мсти-

\footnotetext{
1 Работа выполнена при финансовой поддержке РФФИ (грант № 18-512-76004).
} 
славца (до этого времени в Москве было анонимно выпущено несколько различных книг без указания на место и время печати). 1 марта 1564 г. вышла в свет первая датированная русская книга «Апостол». В послесловии к нему, составленному скорее всего самим Иваном Федоровым, излагается предыстория основания типографии, в которой сообщается, что по решению царя Ивана Грозного люди стали покупать книги на торжищах, но поскольку те оказались испещрены ошибками несведущих переписчиков, велено было на средства царской казны устроить печатный дом и начать печатное дело, «делателями» которого были назначены дьякон церкви Николы Гостунского в Кремле Иван Федоров и Петр Тимофеев Мстиславец.

После издания в Москве «Апостола» первопечатники на следующий год выпустили в свет два издания «Часовника», который использовался на Руси для обучения грамоте. Однако вскоре после этого они были вынуждены покинуть Москву, захватив с собой часть типографских материалов. Сам Иван Федоров объяснял причины своего отъезда бедами, к которым привело озлобление несведущих в грамоте людей. При этом он подчеркивал, что главная беда исходила «не от самого царя, но от многих гражданских и духовных начальников и учителей», которые из зависти обвинили первопечатников «в различных ересях, желая благое превратить во зло». Из-за всего этого, по словам Ивана Федорова, ему вместе с Петром Мстиславцем пришлось покинуть свою страну и переселиться в иные, «неведанные страны», которыми стали земли Великого княжества Литовского и Польша. Здесь первопечатники нашли приют в имении магната Григория Ходкевича Заблудове и вскоре занялись созданием православной типографии. 8 июля 1568 г. они приступили здесь к выпуску первой книги - «Евангелия учительного». Набор первопечатники производили шрифтами, привезенными ими из Москвы. Использовались также изготовленные в России заставки, концовки и буквицы, которые они

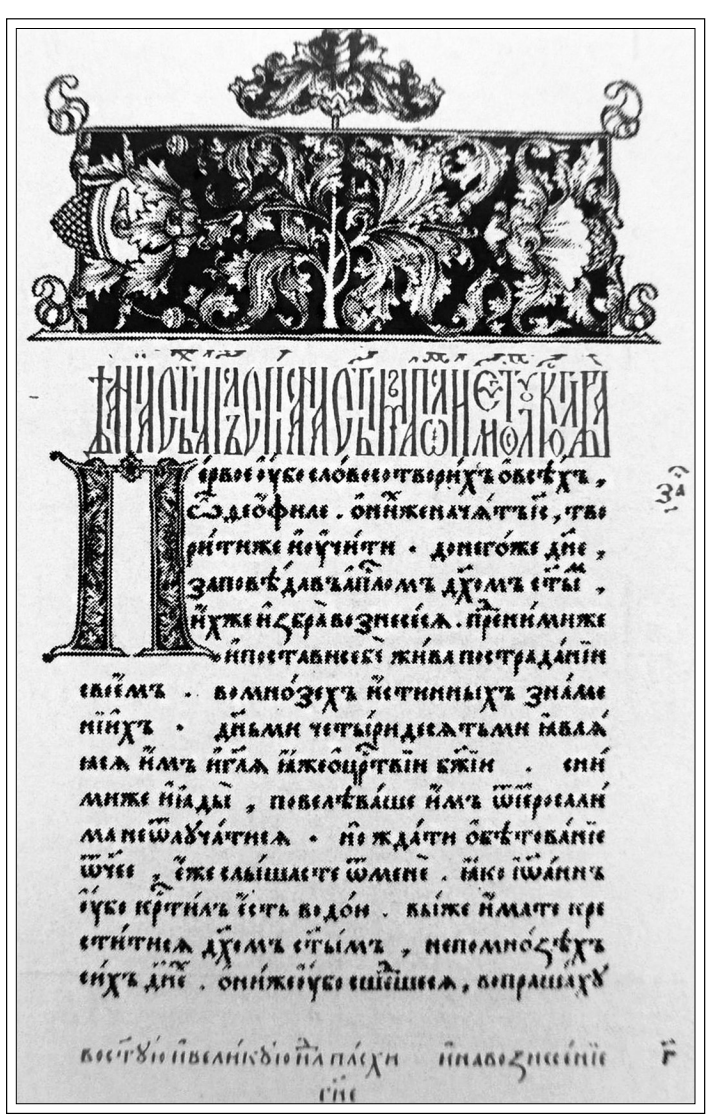

Заглавный лист «Апостола» (M., 1564) 
применили при издании московского «Апостола» 1564 г. 17 марта 1569 г. «Евангелие учительное» было напечатано. Следует отметить, что в состав этой книги вошло и одно из слов знаменитого древнерусского автора XII в. Кирилла Туровского. В 1570 г. здесь же в Заблудове Иван Федоров уже без Петра Мстиславца (который в дальнейшем начал издавать книги в Вильне) выпустил печатную «Псалтырь с Часословцем», которая массово использовалась и для обучения грамоте.

В 1572 г. после решения Ходкевича о закрытии заблудовской типографии Иван Федоров переезжает во Львов, где через два года выпустил знаменитые «Апостол» и «Букварь». Две эти книги положили начало книгопечатанию в украинских землях, а Иван Федоров по праву стал основателем и украинского книгопечатания. Основной текст «Апостола» - первой печатной книги в украинских землях полностью повторял текст московского «Апостола» 1564 г. К нему прилагались три небольшие начальные статьи и обширное послесловие Ивана Федорова о начале книгопечатания. В отличие от Москвы и Заблудова, где он получал большую поддержку сильных мира сего, в том числе и материальную, во Львове Иван Федоров при налаживании книгопечатания не обрел чьей-либо помощи. Здесь он столкнулся с вопиющим равнодушием к своему делу, и лишь некоторые «малого чина» православные священнослужители и незнатные львовские миряне откликнулись на его призыв о содействии.

В 1579 г. Иван Федоров по приглашению князя Константина Острожского прибыл в Острог, куда этот вельможа созывал выдающихся ученых мужей того времени для подготовки и издания текста первой полной печатной Библии на церковнославянском языке. До осуществления ее публикации Иван Федоров напечатал в Остроге «Азбуку» (1578), «Букварь» (около 1580), Псалтырь и Новый Завет (1580), «Книжку собрание вещей нужнейших вкратце скораго ради обретения в книзе Новаго Завета» (1580) и «Хронологию» Андрея Рымши

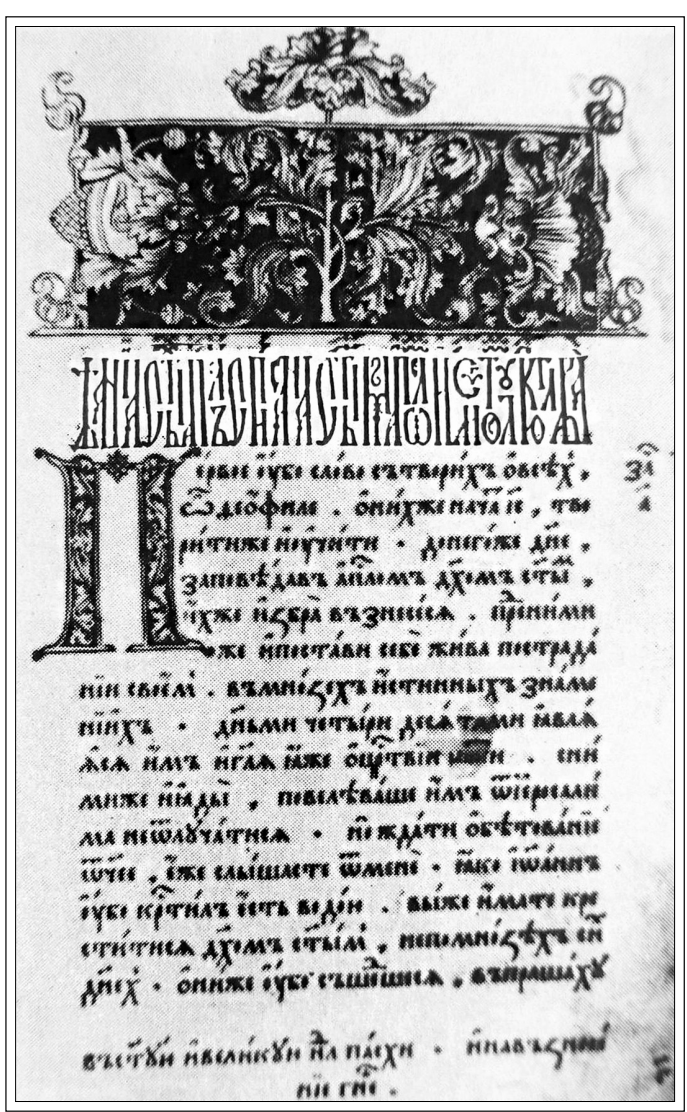

Заглавный лист «Апостола» (Львов, 1574) 
(1581). В ходе подготовки к изданию Библии Иван Федоров значительно расширил и укомплектовал работниками острожскую типографию, собрал потребные типографские материалы и запасся бумагой, необходимой для столь объемного печатного издания. В 1581 г. увидела свет Острожская Библия - замечательный памятник мирового типографского искусства, первая полная библия на церковнославянском языке. Непосредственное участие при подготовке к печати ее рукописи принимал и сам Иван Федоров: он являлся превосходным текстологом и знатоком церковнославянского языка. В начале 1583 г. Иван Федоров возвратился во Львов, где скончался в декабре 1583 г., и был похоронен в Онуфриевском монастыре.

Имя Ивана Федорова широко известно во многих странах мира. Особенно дорого оно людям в России, Беларуси и Украине - там, где его деятельность оставила наиболее глубокий след. Был он личностью выдающейся - духовное лицо, первопечатник, изобретатель, писатель. Как писатель, Иван Федоров оставил нам несколько своих произведений, послесловий к изданиям, особое место среди которых принадлежит послесловию к львовскому «Апостолу» 1574 г. Он озаглавил его «Повестью» - первой в истории литературы печатной повестью русского автора. Но главное из того, что сделал Иван Федоров, относится к его типографской и издательской деятельности. Такого мнения придерживались уже современники первопечатника, выбившие на его могильной плите во Львове следующие слова: «Иоанн Федорович, Друкарь Москвитин, <... Друкарь книг пред тым невиданных».

Книги Ивана Федорова широко разошлись по всему миру. До наших дней сохранилось около 70 экземпляров московского «Апостола» 1564 г. Большая их часть находится в разных городах России, и прежде всего в Москве - треть из всех ныне известных. Экземпляры этой книги имеются также и в ряде других стран: Великобритании, США, Киргизии, Чехии, Латвии и, конечно же, в Украине, где сберегается десятая их часть. Экземпляров Львовского «Апостола» 1574 г. сохранилось почти в два раза больше -130 . Более половины из них находится в России, из них четвертая часть - в Москве. Имеются они и в Польше, Литве, Греции, Великобритании, Австрии, Венгрии, Канаде, Белоруссии, Болгарии, Сербии, Италии, Чехии и Швеции. В самой Украине хранится четверть всех экземпляров львовского «Апостола» 1574 г., из них около половины во Львове. Особая судьба сложилась у заблудовского «Евангелия учительного» 1569 г., которое оказало значительное влияние на православных как внутри Великого княжества Литовского, так и далеко за его пределами, включая Московию и Балканы. Эту книгу в разных странах неоднократно перепечатывали, использовали для работы над другими изданиями, снимали с них рукописные копии, переводили на иные языки. До наших дней дошло около 50 экземпляров заблудовского «Евангелия учительного» 1569 г., находящихся ныне во многих странах на двух континентах: в Польше, США, Сербии, Литве, Украине, Белоруссии и т.д. Больше всего его экземпляров 
имеется в России - во Владимире, Нижнем Новгороде, Санкт-Петербурге, Новосибирске, Петрозаводске, Екатеринбурге и особенно в Москве, где в общей сложности хранится около 20 экземпляров указанного издания. Многочисленные записи на страницах уцелевших экземпляров заблудовского «Евангелия учительного» свидетельствуют о необычайно широком распространении этой книги во всем православном мире. Очень быстро она попадает к болгарам, русским, сербам и другим православным народам, распространяется на территории Великого княжества Литовского и Польского королевства. До наших дней дошло около 400 экземпляров Острожской библии, и почти каждый год обнаруживаются все новые и новые. Они распространены буквально по всему миру, и больше всего их, конечно же, в России и Украине. Затем следуют Сербия, Польша, Великобритания, Болгария и другие страны. Вопрос о тираже Острожской библии окончательно не решен, но по тем временам он, несомненно, был очень большим. Впрочем, огромное число сохранившихся экземпляров этой книги объясняется еще и весьма бережным отношением к этому выдающемуся памятнику славянской книжности. Выход в свет в Остроге в 1581 г. первой церковнославянской печатной Библии не только завершил многовековую историю создания полного «словенского» библейского свода, но и заложил новую прочную основу рецепции в среде многих народов текста Священного Писания, которое служило тысячелетним стержнем всей европейской культурной традиции.

Дьякон кремлевской церкви св. Николая Гостунского «Иван Федоров сын Москвитин» Относится к числу тех исторических личностей, которым выпало стать магистральными проводниками самой широкой и масштабной коммуникации древней церковнославянской традиции, связанной с печатным словом. Многогранная творческая деятельность Ивана Федорова в Москве, на белорусских и украинских землях - одна из самых ярких страниц истории России, Белоруссии и Украины. В истории восточнославянских культурных взаимосвязей, в том числе русско-украинских и украинско-русских, трудно найти пример, столь наглядно демонстрирующий многовековое духовное родство наших народов. За свою непростую скитальческую жизнь, закончившуюся в декабре 1583 г. во Львове, Иван Федоров напечатал целый ряд изданий, ставших классическими и образцовыми не только как предметы мирового типографского искусства, но и как памятники тысячелетней церковнославянской книжной традиции, до сих пор наиболее надежно охраняющей и свидетельствующей о духовно-культурном единстве восточных и южных славян.

Именем Ивана Федорова названы улицы в ряде городов, памятники ему установлены в Москве и Львове, писатели и поэты посвящают ему художественные произведения. 23 июля 2010 г. Московскому государственному университету печати в связи с 80-летием его основания было присвоено имя Ивана Федорова. 


\section{ЛИТЕРАТУРА}

Немировский ЕЛ. Иван Федоров и его эпоха: Энциклопедия. М., 2007.

Лабынщев Ю., Щавинская Л. «Напечатана... Иваном Федоровым... Москвитином». M., 2007.

Немировский ЕЛ. Иван Федоров. Начало книгопечатания на Руси: Описание изданий и указатель литературы: к 500-летию со дня рождения великого русского просветителя. М., 2010.

\section{СПИСОК ИЛЛЮСТРАЦИЙ}

1. Заглавный лист «Апостола». М., 1564.

2. Начальная страница послесловия в «Апостоле». М., 1564.

3. Выходной лист «Евангелия учительного». Забудов, 1569.

4. Заглавный лист «Псалтыря с Часословцем». Заблудов, 1574.

5. Заглавный лист «Апостола». Львов, 1574.

6. Начальная страница послесловия в «Апостоле». Львов, 1574.

7. Выходные сведения «Букваря». Львов, 1574.

8. Титульный лист «Библии». Острог, 1581.

9. Памятник Ивану Федорову в Москве. Скульптор С.М. Волнухин. 1909 г.

10. Памятник Ивану Федорову во Львове. Скульпторы В.Н. Борисенко и В.М. Подольский. 1977 г. 